Fetal Diagnosis and Therapy
Fetal Diagn Ther 2014;35:1-6

DOI: $10.1159 / 000357198$
Received: October 7, 2013

Accepted after revision: November 8, 2013

Published online: December 11, 2013

\title{
Assessment of Fetal Sex Chromosome Aneuploidy Using Directed Cell-Free DNA Analysis
}

\author{
Kypros H. Nicolaides ${ }^{a, b}$ Thomas J. Muscic Craig A. Struble ${ }^{c}$ Argyro Syngelaki $^{a}$ \\ Maria del Mar Gil ${ }^{a}$ \\ a Harris Birthright Research Centre for Fetal Medicine, King's College Hospital, and ${ }^{b}$ Department of Fetal Medicine, \\ University College Hospital, London, UK; ' Ariosa Diagnostics Inc., San Jose, Calif., USA
}

\section{Key Words}

Non-invasive prenatal testing · Fetal aneuploidy · Sex

chromosome aneuploidy · First-trimester screening

\begin{abstract}
Objective: To examine the performance of chromosome-selective sequencing of cell-free (cf) DNA in maternal blood for assessment of fetal sex chromosome aneuploidies. Methods: This was a case-control study of 177 stored maternal plasma samples, obtained before fetal karyotyping at 11-13 weeks of gestation, from 59 singleton pregnancies with fetal sex chromosome aneuploidies $(45, X, n=49 ; 47, X X X, n=6$; $47, X X Y, n=1 ; 47, X Y Y, n=3$ ) and 118 with euploid fetuses $(46, X Y, n=59 ; 46, X X, n=59)$. Digital analysis of selected regions (DANSR ${ }^{\mathrm{TM}}$ ) on chromosomes $21,18,13, \mathrm{X}$ and $\mathrm{Y}$ was performed and the fetal-fraction optimized risk of trisomy evaluation (FORTE ${ }^{\top M}$ ) algorithm was used to estimate the risk for non-disomic genotypes. Performance was calculated at a risk cut-off of 1:100. Results: Analysis of cfDNA provided risk scores for 172 (97.2\%) samples; 4 samples $(45, X, n=2 ; 46, X Y$, $n=1 ; 46, X X, n=1)$ had an insufficient fetal cfDNA fraction for reliable testing and 1 case $(47, X X X)$ failed laboratory quality control metrics. The classification was correct in 43 (91.5\%) of 47 cases of $45, X$, all 5 of $47, X X X, 1$ of $47, X X Y$ and 3 of $47, X Y Y$.
\end{abstract}

There were no false-positive results for monosomy X. Discussion: Analysis of cfDNA by chromosome-selective sequencing can correctly classify fetal sex chromosome aneuploidy with reasonably high sensitivity.

(c) 2013 S. Karger AG, Basel

\section{Introduction}

Prenatal screening for fetal aneuploidies has traditionally focused on trisomy 21 , and more recently on trisomies 18 and 13. Sex chromosome aneuploidies, including monosomy X $(45, \mathrm{X})$, Klinefelter syndrome (47,XXY or $48, \mathrm{XXYY})$, Triple X syndrome (47,XXX), and 47,XYY, with a combined prevalence of 1:500 are more common than the major trisomies [1-3]. Although most cases of sex chromosome aneuploidies are generally mild without intellectual disability, some have a well-established phenotype that can include physical abnormalities, learning delays and infertility [1-3]. It may therefore be desirable to some parents that these conditions could be diagnosed prenatally with the option of pregnancy termination [410]. However, the traditional methods of screening for trisomies, including maternal age, maternal serum biochemical testing and ultrasound examination of the fetus,

\begin{tabular}{ll}
\hline KARGER & $\begin{array}{l}\text { ( ) 2013 S. Karger AG, Basel } \\
1015-3837 / 13 / 0351-0001 \$ 38.00 / 0 \quad \text { Karger }\end{array}$ \\
$\begin{array}{l}\text { E-Mail karger@karger.com } \\
\text { www.karger.com/fdt }\end{array}$ & $\begin{array}{l}\text { This is an Open Access article licensed under the terms of the } \\
\text { Creative Commons Attribution-NonCommercial 3.0 Un- } \\
\text { ported license (CC BY-NC) (www.karger.com/OA-license), } \\
\text { applicable to the online version of the article only. Distribu- } \\
\text { tion permitted for non-commercial purposes only. }\end{array}$
\end{tabular}

Prof. K.H. Nicolaides

Harris Birthright Research Centre for Fetal Medicine

King's College Hospital, Denmark Hill

London SE5 9RS (UK)

E-Mail kypros@fetalmedicine.com 
are not effective in detecting sex chromosome aneuploidies, except cases of Turner syndrome presenting with cystic hygromas.

The introduction of cell-free (cf) DNA analysis in maternal blood has now made it possible to screen not only for trisomies 21, 18 and 13, but also potentially for other aneuploidies, including sex chromosome aneuploidies. Chromosome-selective sequencing of cfDNA, referred to as digital analysis of selected regions (DANSR ${ }^{\mathrm{TM}}$ ), combined with an algorithm (fetal-fraction optimized risk of trisomy evaluation; FORTE ${ }^{\mathrm{TM}}$ ) that accounts for a priori risk factors and fetal fraction, has been shown in a variety of clinical settings to provide an accurate risk assessment for trisomies 21, 18 and 13 [11-18]. This same approach lends itself to possible expansion of the testing platform to include evaluation of chromosomes $\mathrm{X}$ and $\mathrm{Y}$. The objective of this case-control study is to report the clinical performance of chromosome-selective sequencing of cfDNA in maternal blood and the FORTE algorithm for the assessment of fetal sex chromosome aneuploidies.

\section{Methods}

\section{Study Population}

This was a case-control study of 177 stored maternal plasma samples from 59 singleton pregnancies with fetal sex chromosome aneuploidies (45,X, $\mathrm{n}=49$; 47, XXX, $\mathrm{n}=6$; 47, XXY, $\mathrm{n}=1$; 47,XYY, $\mathrm{n}=3)$ and 118 with euploid fetuses $(46, X Y, n=59 ; 46, X X, n=59)$. No cases of fetal mosaicism were included. All samples were collected before invasive testing for fetal karyotyping at 11-13 weeks of gestation because screening by the combined test of maternal age, fetal nuchal translucency (NT) thickness and serum free $\beta$-hCG and PAPP-A indicated an increased risk for fetal trisomies [19]. Gestational age was determined from the measurement of the fetal crown-rump length [20].

Maternal venous blood $(10 \mathrm{ml})$ collected before chorionic villous sampling in ethylene-diamine-tetraacetic acid, EDTA, BD Vacutainer ${ }^{\mathrm{TM}}$ tubes (Becton Dickinson UK Ltd., Oxford, UK) was processed within $15 \mathrm{~min}$ of collection. The samples were centrifuged at 2,000 $\mathrm{g}$ for $10 \mathrm{~min}$ to separate the plasma from packed cells and buffy coat, and subsequently at $16,000 \mathrm{~g}$ for $10 \mathrm{~min}$ to further separate cell debris. Plasma samples $(2 \mathrm{ml}$ each) were divided into $0.5-\mathrm{ml}$ aliquots in separate eppendorf tubes, which were labeled with a unique patient identifier and stored at $-80^{\circ} \mathrm{C}$ until subsequent analysis. The study was approved by the UK NHS Research Ethics Committee and all patients gave written informed consent to participate.

We searched our database and selected 59 cases of sex chromosome aneuploidies with available stored plasma and then selected samples from 59 pregnancies with euploid male fetuses and 59 with euploid female fetuses. Plasma samples ( 4 tubes of $0.5 \mathrm{ml}$ per patient) from selected cases were sent overnight on dry ice from London to the USA for cfDNA analysis (Harmony ${ }^{\mathrm{TM}}$ Prenatal Test, Ariosa Diagnostics Inc., San Jose, Calif., USA). The information given to the laboratory for each case was: the patient unique identifier, maternal age, maternal weight, method of conception and date of blood collection. The laboratory was informed that the samples were collected from pregnancies with sex chromosome aneuploidies and euploid controls, but not the karyotype of individual samples.

\section{Laboratory Analysis}

cfDNA was extracted from maternal plasma, chromosome-selective sequencing with DANSR was carried out and analyzed using a FORTE algorithm as previously described [11, 12]. All laboratory personnel were blinded to the identity and origin of plasma samples.

DANSR on chromosomes $21,18,13, \mathrm{X}$ and $\mathrm{Y}$ was performed and a FORTE algorithm was used to estimate risk for non-disomic genotypes $[11,12]$. For assessment of risk for sex chromosome aneuploidies, the original DANSR assays were expanded to include 32 regions on chromosome Y and 599 on chromosome X. Similarly, the FORTE algorithm used to assess trisomies 21, 18 and 13 $[11,12]$ was adapted to assess sex chromosome aneuploidies. Models of observing proportions of median $\mathrm{Y}$ or $\mathrm{X}$ assay counts relative to median assay counts on chromosomes 13,18 , and 21 were based on normal or truncated normal (in the case of no Y presence) distributions using standard deviations estimated by Monte Carlo simulations. All models assuming Y chromosome copy counts of 0,1 or 2 , and $\mathrm{X}$ chromosome copy counts of 1,2 or 3 were constructed and combined to consider joint probabilities representing genotypes of monosomy X, XX, XY, XXX, XXY, XYY and XXYY, making the assumption that observed $X$ and $Y$ proportions are independent.

For example, in the case of 45,X the model can be described by the formula:

$$
\mathrm{P}\left(\mathrm{p}_{\mathrm{X}} \mid \mathrm{X}=1, \mathrm{f}\right) \mathrm{P}\left(\mathrm{p}_{\mathrm{Y}} \mid \mathrm{Y}=0, \mathrm{f}\right) \mathrm{P}(\mathrm{X}=1, \mathrm{Y}=0 \mid \mathrm{MA}, \mathrm{GA}),
$$

where $p_{X}$ is the proportion of $X$ assay counts, $p_{Y}$ is the proportion of $\mathrm{Y}$ assay counts, $\mathrm{f}$ is the observed fetal fraction, and $\mathrm{P}(\mathrm{X}=1$, $\mathrm{Y}=0 \mid \mathrm{MA}, \mathrm{GA})$ is the prevalence of monosomy $\mathrm{X}$ for the given maternal age (MA) and gestational age (GA). Values derived from these models were normalized using the standard Bayesian approach of summing values across all possible genotypes to obtain a final score for each genotype. Non-disomic genotypes were reported when their score was above 1 in 10,000, otherwise the disomic genotype with the highest score was reported as long as it was greater than 99\%. A risk cut-off of 1 in 100 for non-disomic genotypes was used for calculation of the detection rate (DR) and falsepositive rate (FPR)

\section{Results}

Maternal and pregnancy characteristics of the study population are summarized in table 1 . In the euploid group, the median maternal age (36 years), NT thickness $(2.8 \mathrm{~mm})$ and serum-free $\beta$-hCG $(1.4$ multiples of the normal medium; MoM) were higher and serum PAPP-A $(0.7 \mathrm{MoM})$ was lower than the respective values of 31 years, $1.8 \mathrm{~mm}, 1.0$ and $1.0 \mathrm{MoM}$ in more than 87,000 
Table 1. Maternal and pregnancy characteristics of the study population

\begin{tabular}{lccc}
\hline Characteristics & $\begin{array}{l}\text { Euploid } \\
(\mathrm{n}=118)\end{array}$ & $\begin{array}{l}\text { Monosomy X } \\
(\mathrm{n}=49)\end{array}$ & $\begin{array}{l}47, \mathrm{XXX}, 47, \mathrm{XXY}, 47, \mathrm{XYY} \\
(\mathrm{n}=10)\end{array}$ \\
\hline Maternal age, years & $36.1(17.3-46.4)$ & $29.4(18.0-40.6)$ & $38.7(29.1-47.8)$ \\
Maternal weight, $\mathrm{n}$ & $63.0(42.0-111.4)$ & $63.5(47.0-102.8)$ & $68.5(59.0-103.0)$ \\
Racial origin & & & \\
$\quad$ Caucasian & $108(91.5)$ & $42(85.7)$ & $10(100.0)$ \\
$\quad$ Afro-Caribbean & $4(3.4)$ & $3(6.1)$ & 0 \\
$\quad$ Asian & $6(5.1)$ & $3(6.1)$ & 0 \\
Spontaneous conception & $109(92.4)$ & $47(95.9)$ & $9(90.0)$ \\
Gestational age, weeks & $13.1(11.3-14.1)$ & $12.5(11.2-13.7)$ & $13.0(12.6-13.9)$ \\
Crown-rump length, mm & $69.1(45.4-84.3)$ & $60.6(45.0-78.2)$ & $68.0(61.8-81.1)$ \\
NT, mm & $2.8(1.2-8.6)$ & $8.3(1.8-16.0)$ & $2.9(1.7-5.0)$ \\
Serum-free $\beta$-hCG in MoM & $1.487(0.220-10.915)$ & $0.913(0.181-10.139)$ & $0.759(0.360-1.671)$ \\
Serum PAPP-A in MoM & $0.733(0.148-3.960)$ & $0.415(0.183-1.307)$ & $0.676(0.222-1.669)$ \\
Fetal fraction, \% & $13.0(4.8-32.0)$ & $10.0(6.3-18.0)$ & $12.0(6.4-16.0)$ \\
\hline
\end{tabular}

Values are median with range in parentheses, or number with percentage in parentheses.

pregnancies which had first trimester combined screening in our center [21]. In monosomy $\mathrm{X}$, the maternal age and serum-free $\beta$-hCG were similar to our screened population, but the median fetal NT $(8.3 \mathrm{~mm})$ was very much higher and serum PAPP-A (0.4 MoM) was lower; the NT was $\geq 3.5 \mathrm{~mm}$ in $45(91.8 \%)$ of the 49 cases. In the group with other sex chromosome aneuploidies, compared to our screened population, median maternal age and fetal NT were higher, but serum-free $\beta-h C G$ and PAPP-A were lower.

Analysis of cfDNA provided risk scores for 172 (97.2\%) of the samples. Four samples $(45, \mathrm{X}, \mathrm{n}=2 ; 46, \mathrm{XY}, \mathrm{n}=1$; $46, \mathrm{XX}, \mathrm{n}=1$ ) had an insufficient fetal cfDNA fraction for reliable testing and 1 case $(47, \mathrm{XXX})$ failed laboratory quality control metrics.

In the 172 cases with risk scores, the median fetal fraction was $12.0 \%$ (range $4.8-32.0 \%$ ). The performance of screening by cfDNA analysis in the assessment of sex chromosome aneuploidies is summarized in table 2. The classification was correct in 43 (91.5\%) of 47 cases of $45, X$, all 5 with 47,XXX, 1 of 47,XXY and 3 of 47,XYY. In 115 of the 116 euploid pregnancies with results, the classifications were correct, but in 1 case of 46,XX the classification was $47, \mathrm{XXX}$ with a risk score of 55 in 100 .

The distribution of estimated risk for monosomy X by cfDNA analysis in maternal blood from pregnancies with $45, \mathrm{X}$ and euploid fetuses, plotted against fetal fraction is shown in figure 1 . There were 39 cases with a risk of $>99$ in 100, and 1 each with a risk of 91 in 100, 90 in 100, 80 in 100, 2.8 in 100, 1.6 in 100, 1 in 285, 1 in 2,500, and 1 in
Table 2. cfDNA analysis of maternal blood in screening for sex chromosome aneuploidies

\begin{tabular}{lrlllllll}
\hline Karyotype & \multirow{2}{*}{ Total } & \multicolumn{6}{l}{ cfDNA analysis } \\
\cline { 3 - 8 } & & no result & XX & XY & XO & XXX & XXY & XYY \\
\hline $45, \mathrm{X}$ & 49 & 2 & 3 & 1 & 43 & & & \\
$47, \mathrm{XXX}$ & 6 & 1 & & & & 5 & & \\
$47, \mathrm{XXY}$ & 1 & 0 & & & & & 1 & 3 \\
$47, \mathrm{XYY}$ & 3 & 0 & & & & 1 & & \\
$46, \mathrm{XX}$ & 59 & 1 & 57 & & & & & \\
$46, \mathrm{XY}$ & 59 & 1 & & 58 & & &
\end{tabular}

7,692 and $<1$ in 10,000. Consequently, 4 of the 47 cases were classified as screen negative because the risk was below the pre-specified cut-off of 1 in 100; 3 were classified as normal female and 1 as normal male. In the euploid pregnancies there were no false-positive cases for monosomy X.

\section{Discussion}

The findings of this study demonstrate the feasibility of chromosome-selective sequencing of cfDNA in maternal blood for assessment of risk for fetal monosomy X and other sex chromosome aneuploidies; $91.5 \%$ of cases of 45 , X were identified at an FPR of $0 \%$. Although all cases with 47,XYY, 47,XXY and 47,XXX were correctly classi- 


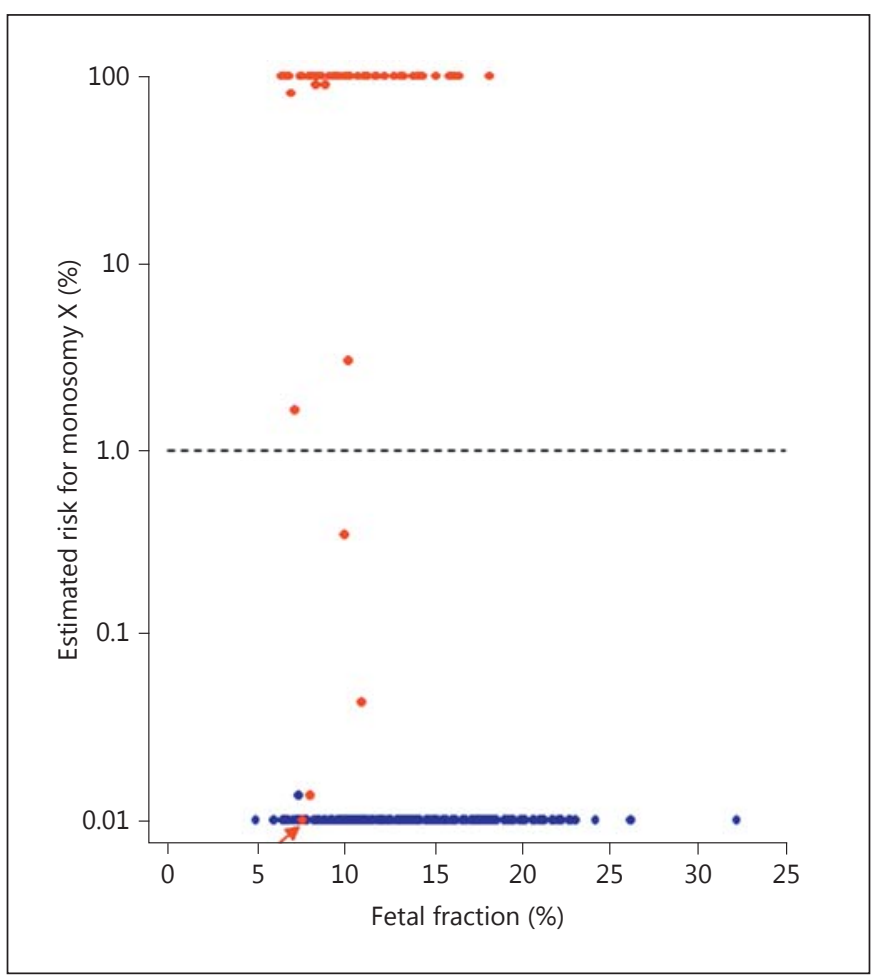

Fig. 1. Estimated risk for monosomy $\mathrm{X}$ by cfDNA analysis in maternal blood from pregnancies with 45,X (red circles; colors refer to the online version only) and euploid fetuses (blue circles). The cut-off risk for classifying pregnancies as monosomy $\mathrm{X}$ is $0.1 \%$.

fied, the number of cases examined is too small for definite conclusions to be drawn for the performance of screening for these aneuploidies.

Several studies have reported on the feasibility of cfDNA analysis in the diagnosis of $45, \mathrm{X}$ and other sex chromosome aneuploidies, but only four studies have examined more than 10 cases. Bianchi et al. [22] carried out massively parallel shotgun sequencing (MPSS) in 20 cases of $45, X$ and 462 non $45, X$. In the 45 , $X$ group, 15 were classified correctly, 1 was classified as non- $45, \mathrm{X}$ and 4 were unclassified, giving a DR of $75.0 \%$. In the non- $45, X$, 416 were classified correctly, 1 was classified as $45, \mathrm{X}$ and 45 were unclassified, giving an FPR of $0.2 \%$. It is of interest that in the case of trisomies 21,18 and 13 the rate of unclassified result was only $0.4-1.4 \%$, compared to $9.9 \%$ for 45,X. Similarly, Mazloom et al. [23] carried out MPSS in 21 cases of 45,X and 390 non-45,X. The result from cfDNA analysis was unclassified in $21(5.1 \%)$ cases $(45, \mathrm{X}$, $\mathrm{n}=3$; non-45,X, $\mathrm{n}=18$ ) and the overall $\mathrm{DR}$ and FPR were 81.0 and $0.3 \%$, respectively. A proof of principle study investigating the feasibility of developing a genome-wide assay of cfDNA in maternal plasma capable of replacing invasive testing for major aneuploidies, which used MPSS at 20 million reads per sample in 176 pregnancies, correctly classified all 15 cases of 45,X at an FPR of $0 \%$ [24]. Samango-Sprouse et al. [25] used targeted sequencing and allelic ratio analysis of SNPs covering chromosomes $21,18,13, \mathrm{X}$ and $\mathrm{Y}$, to examine 13 cases of $45, \mathrm{X}$ and 188 non-45,X. In 14 (7.0\%) cases, including 1 case of 45,X, the samples did not pass quality control. In those with results, the DR and FPR for 45 ,X were 91.7 and $0 \%$, respectively. The DR of monosomy $\mathrm{X}$ from the combined data of these four studies was $87 \%$ (59 of 68 ) at FPR of $0.2 \%(2$ of 1,188$)$ [22-25].

The poorer performance of cfDNA analysis in screening for X chromosome aneuploidy, as well as trisomy 13 compared to trisomies 21 and 18 using MPSS technology could, at least in part, be due to the highly variable amplification of chromosomes $\mathrm{X}$ and 13 because of lower guanosine-cytosine content [26-29]. This would not be a factor for the DANSR methodology as loci selection avoids regions of the chromosome where this is an issue.

An additional factor that complicates cfDNA screening for sex chromosome aneuploidies is the high incidence of maternal and fetal mosaicism for these aneuploidies. For example, fetal mosaicism can account for up to $50 \%$ of sex aneuploidy cases $[2,3,30,31]$. This could result in a quantitative assessment of the $\mathrm{X}$ and $\mathrm{Y}$ chromosome from cfDNA analysis which is not concordant with the fetal karyotype as assessed by either CVS or amniocentesis. In the case of maternal sex chromosome mosaicism, whether previously known or unknown at the time of testing, the assay might result in counts of $\mathrm{X}$ chromosome fragments predicted as a fetal sex chromosome aneuploidy when in fact the fetus is euploid. In normal females there is an age-related loss of an X chromosome in white blood cells [32]. Moreover, an unknown maternal karyotype of 47,XXX could confound assay results because up to $90 \%$ of such women are not aware that they have a third X chromosome [3]. A limitation of our study was that we did not perform maternal karyotyping to determine if there were any cases of mosaicism.

Conventional prenatal screening has never directly sought to uncover fetal sex chromosome aneuploidies, and their detection was coincidental in pregnancies undergoing invasive testing following screening for trisomy $21[33,34]$. The objective of screening for trisomy 21 over the last 4 decades has been to increase the DR and decrease the rate of unnecessary invasive tests. Such decrease in invasive testing would inevitably reduce the coincidental detection of sex chromosome aneuploidies 
other than monosomy X. In patients presenting with very high fetal NT during the first trimester or cystic hygromas/hydrops during the second trimester, it could be argued that the investigation of choice would be invasive testing for fetal karyotype evaluation, including a subchromosomal analysis with microarray [35], rather than cfDNA analysis for assessment of risk for $45, \mathrm{X}$.

This study has confirmed the feasibility of cfDNA analysis in the assessment of risk for fetal monosomy $\mathrm{X}$ and other sex chromosome aneuploidies. Whether or not we should be screening the pregnant population for these aneuploidies, in light of their wide yet mild phenotypic spectrum and the possibility of uncovering a previously unknown aneuploidy in the mother, warrants further consideration of both individual patient preferences and the clinical utility of such an endeavor. Another important factor to be considered in expanding the indications of cfDNA testing from screening for trisomies to include sex chromosome and other aneuploidies is the decrease in efficiency of screening because of the likely increase in cumulative FPR.

\section{Acknowledgments}

The study was supported by a grant from The Fetal Medicine Foundation (UK Charity No. 1037116). Analysis of samples was performed at their own expense by Ariosa Diagnostics (San Jose, Calif., USA).

\section{References}

1 Nussbaum RL, McInnes RR, Willard HF, Thompson MW: Thompson and Thompson Genetics in Medicine, ed 6. Philadelphia, Saunders, 2004.

2 Visootsak J, Graham JM Jr: Klinefelter syndrome and other sex chromosomal aneuploidies. Orphanet J Rare Dis 2006;1:42.

-3 Tartaglia NR, Howell S, Sutherland A, Wilson R, Wilson L: A review of trisomy X (47,XXX). Orphanet J Rare Dis 2010;5:8.

4 Forrester MB, Merz RD: Pregnancy outcome and prenatal diagnosis of sex chromosome abnormalities in Hawaii, 1986-1999. Am J Med Genet A 2003;119A:305-310.

5 Brun JL, Gangbo F, Wen ZQ, Galant K, Taine L, Maugey-Laulom B, Roux D, Mangione R, Horovitz J, Saura R: Prenatal diagnosis and management of sex chromosome aneuploidy: a report on 98 cases. Prenat Diagn 2004;24: 213-218.

-6 Vaknin Z, Reish O, Ben-Ami I, Heyman E, Herman A, Maymon R: Prenatal diagnosis of sex chromosome abnormalities: the 8-year experience of a single medical center. Fetal Diagn Ther 2008;23:76-81

7 Boyd PA, Loane M, Garne E, Khoshnood B, Dolk H, EUROCAT working group: Sex chromosome trisomies in Europe: prevalence, prenatal detection and outcome of pregnancy. Eur J Hum Genet 2011;19:231234.

8 Gruchy N, Vialard F, Decamp M, Choiset A, Rossi A, Le Meur N, Moirot H, Yardin C, Bonnet-Dupeyron MN, Lespinasse J, Herbaut-Graux M, Till M, Layet V, Leporrier N: Pregnancy outcomes in 188 French cases of prenatally diagnosed Klinefelter syndrome. Hum Reprod 2011;26:2570-2575.

9 Jeon KC, Chen LS, Goodson P: Decision to abort after a prenatal diagnosis of sex chromosome abnormality: a systematic review of the literature. Genet Med 2012;14:27-38.
10 Iyer NP, Tucker DF, Roberts SH, Moselhi M, Morgan M, Matthes JW: Outcome of fetuses with Turner syndrome: a 10-year congenital anomaly register based study. J Matern Fetal Neonatal Med 2012;25:68-73.

-11 Sparks AB, Wang ET, Struble CA, Barrett W, Stokowski R, McBride C, Zahn J, Lee K, Shen N, Doshi J, Sun M, Garrison J, Sandler J, Hollemon D, Pattee P, Tomita-Mitchell A, Mitchell M, Stuelpnagel J, Song K, Oliphant A: Selective analysis of cell-free DNA in maternal blood for evaluation of fetal trisomy. Prenat Diagn 2012;32:1-7.

$\checkmark 12$ Sparks AB, Struble CA, Wang ET, Song K, Oliphant A: Noninvasive prenatal detection and selective analysis of cell-free DNA obtained from maternal blood: evaluation for trisomy 21 and trisomy 18. Am J Obstet Gynecol 2012;206:319.e1-e9.

13 Ashoor G, Syngelaki A, Wagner M, Birdir C, Nicolaides KH: Chromosome-selective sequencing of maternal plasma cell-free DNA for first-trimester detection of trisomy 21 and trisomy 18. Am J Obstet Gynecol 2012;206: 322.e1-e5.

14 Nicolaides KH, Syngelaki A, Ashoor G, Birdir C, Touzet G: Noninvasive prenatal testing for fetal trisomies in a routinely screened firsttrimester population. Am J Obstet Gynecol 2012;207:374.e1-e6.

15 Norton ME, Brar H, Weiss J, Karimi A, Laurent LC, Caughey $\mathrm{AB}$, Rodriguez $\mathrm{MH}$, Williams J 3rd, Mitchell ME, Adair CD, Lee H, Jacobsson B, Tomlinson MW, Oepkes D, Hollemon D, Sparks AB, Oliphant A, Song K: Non-invasive chromosomal evaluation (NICE) study: results of a multicenter prospective cohort study for detection of fetal trisomy 21 and trisomy 18. Am J Obstet Gynecol 2012;207:137.e1-e8.

16 Ashoor G, Syngelaki A, Wang E, Struble C, Oliphant A, Song K, Nicolaides KH: Trisomy
13 detection in the first trimester of pregnancy using a chromosome-selective cell-free DNA analysis. Ultrasound Obstet Gynecol 2013;41:21-25.

17 Gil MM, Quezada MS, Bregant B, Ferraro M, Nicolaides KH: Implementation of maternal blood cell-free DNA testing in early screening for aneuploidies. Ultrasound Obstet Gynecol 2013;42:34-40.

18 Gil MM, Quezada MS, Bregant B, Syngelaki A, Nicolaides KH: Cell-free DNA analysis for trisomy risk assessment in first trimester twin pregnancies. Fetal Diagn Ther 2013. DOI: 10.1159/000356495.

19 Kagan KO, Wright D, Valencia C, Maiz N, Nicolaides KH: Screening for trisomies 21, 18 and 13 by maternal age, fetal nuchal translucency, fetal heart rate, free $\beta$-hCG and pregnancy-associated plasma protein-A. Hum Reprod 2008;23:1968-1975.

20 Robinson HP, Fleming JE: A critical evaluation of sonar crown rump length measurements. $\mathrm{Br}$ J Obstet Gynaecol 1975;182:702-710.

21 Wright D, Syngelaki A, Bradbury I, Akolekar R, Nicolaides KH: First trimester screening for trisomies 21, 18 and 13 by ultrasound and biochemical testing. Fetal Diagn Ther 2013. DOI: $10.1159 / 000356495$.

-22 Bianchi DW, Platt LD, Goldberg JD, Abuhamad AZ, Sehnert AJ, Rava RP: Genome-wide fetal aneuploidy detection by maternal plasma DNA sequencing. Obstet Gynecol 2012; 119:890-901.

23 Mazloom AR, Džakula Ž, Oeth P, Wang H, Jensen T, Tynan J, McCullough R, Saldivar JS, Ehrich M, van den Boom D, Bombard AT, Maeder M, McLennan G, Meschino W, Palomaki GE, Canick JA, Deciu C: Noninvasive prenatal detection of sex chromosomal aneuploidies by sequencing circulating cell-free DNA from maternal plasma. Prenat Diagn 2013;33:591-597. 
24 Guex N, Iseli C, Syngelaki A, Pescia G, Nicolaides KH, Xenarios I, Conrad B: A robust 2nd generation genome-wide test for fetal aneuploidy based on shotgun sequencing cell-free DNA in maternal blood. Prenat Diagn 2013; 33:707-710.

-25 Samango-Sprouse C, Banjevic M, Ryan A, Sigurjonsson S, Zimmermann B, Hill M, Hall MP, Westemeyer M, Saucier J, Demko Z, Rabinowitz M: SNP-based non-invasive prenatal testing detects sex chromosome aneuploidies with high accuracy. Prenat Diagn 2013;33:643-649.

26 Chen EZ, Chiu RW, Sun H, Akolekar R, Chan KC, Leung TY, Jiang P, Zheng YW, Lun FM, Chan LY, Jin Y, Go AT, Lau ET, To WW, Leung WC, Tang RY, Au-Yeung SK, Lam H, Kung YY, Zhang X, van Vugt JM, Minekawa R, Tang MH, Wang J, Oudejans CB, Lau TK, Nicolaides KH, Lo YM: Noninvasive prenatal diagnosis of fetal trisomy 18 and trisomy 13 by maternal plasma DNA sequencing. PLoS One 2011;6:e21791.
27 Fan HC, Blumenfeld YJ, Chitkara U, Hudgins L, Quake SR: Noninvasive diagnosis of fetal aneuploidy by shotgun sequencing DNA from maternal blood. Proc Natl Acad Sci USA 2008;105:266-271.

28 Dohm JC, Lottaz C, Borodina T, Himmelbauer H: Substantial biases in ultra-short read data sets from high-throughput DNA sequencing. Nucleic Acids Res 2008;36:e105.

29 Alkan C, Kidd JM, Marques-Bonet T, Aksay G, Antonacci F, Hormozdiari F, Kitzman JO, Baker C, Malig M, Mutlu O, Sahinalp SC, Gibbs RA, Eichler EE: Personalized copy number and segmental duplication maps using nextgeneration sequencing. Nat Genet 2009;41:1061-1067.

30 Held KR, Kerber S, Kaminsky E, Singh S, Goetz P, Seemanova E, Goedde HW: Mosaicism in 45,X Turner syndrome: does survival in early pregnancy depend on the presence of two sex chromosomes? Hum Genet 1992;88: 288-294.
31 Papp C, Beke A, Mezei G, Szigeti Z, Bán Z, Papp Z: Prenatal diagnosis of Turner syndrome: report of 69 cases. J Ultrasound Med 2006;25:711-717.

32 Russell LM, Strike P, Browne CE, Jacobs PA: $\mathrm{X}$ chromosome loss and ageing. Cytogenet Genome Res 2007;116:181-185.

33 Sebire NJ, Snijders RJ, Brown R, Southall T, Nicolaides KH: Detection of sex chromosome abnormalities by nuchal translucency screening at $10-14$ weeks. Prenat Diagn 1998;18: 581-584.

34 Spencer K, Tul N, Nicolaides KH: Maternal serum free $\beta$-hCG and PAPP-A in fetal sex chromosome defects in the first trimester. Prenatal Diagnosis 2000;20:390-394.

35 Leung TY, Vogel I, Lau TK, Chong W, Hyett JA, Petersen OB, Choy KW: Identification of submicroscopic chromosomal aberrations in fetuses with increased nuchal translucency and apparently normal karyotype. Ultrasound Obstet Gynecol 2011;38:314-319. 